\title{
Two Different Mechanisms of Calcium Spike Modulation by Dopamine ${ }^{1}$
}

\author{
DANIELE PAUPARDIN-TRITSCH, LAURA COLOMBAIONI, ${ }^{2}$ PHILIPPE DETERRE, ${ }^{3}$ AND \\ HERSCH M. GERSCHENFELD ${ }^{4}$
}

Laboratoire de Neurobiologie, Ecole Normale Supérieure, 46 Rue d'Ulm, 75230 Paris Cedex 05, France

\begin{abstract}
Dopamine (10 to $50 \mu \mathrm{m}$ ) modulates in two different ways the duration of the $\mathrm{Ca}^{2+}$-dependent action potential recorded in the cell body of identified neurons of the snail Helix aspersa. In some neurons (cells E13 and F1) dopamine increases the amplitude of their $\mathrm{Ca}^{2+}$-dependent spike plateau by decreasing the S-current (Klein, M., J. S. Camardo, and E. R. Kandel (1982) Proc. Natl. Acad. Sci. U. S. A. 79: 57135717), a $\mathrm{K}^{+}$current controlled by cyclic AMP. In another neuron (cell D2), dopamine decreases the $\mathrm{Ca}^{2+}$-dependent plateau of the somatic action potential by evoking a decrease in $\mathrm{Ca}^{2+}$-current resulting from a decrease in $\mathrm{Ca}^{2+}$ conductance. Both modulatory effects could be observed in the same single neuron in which dopamine induces decreases of both the $\mathrm{Ca}^{2+}$ conductance and cyclic AMP-dependent $\mathrm{K}^{+}$conductance. Nevertheless, in these cells (such as cell F5) dopamine only evokes a decrease of the amplitude of the $\mathrm{Ca}^{2+}$ spike plateau. Since the modulation of the duration of the $\mathrm{Ca}^{2+}$ action potential recorded in the neuronal soma has been shown to constitute a good model of events taking place at synaptic endings, it is suggested that these modulatory mechanisms evoked by dopamine may be involved in processes of presynaptic facilitation and inhibition.
\end{abstract}

The cell body membrane of molluscan neurons has been one of the preparations of choice in the study of $\mathrm{Ca}^{2+}$ channels (see Kostyuk, 1980; Hagiwara and Byerly, 1981), since a great number of the large cell bodies of these neurons carry a composite action potential involving both $\mathrm{Ca}^{2+}$ and $\mathrm{Na}^{+}$ions.

In recent years, a convincing body of evidence has been accumulated indicating that the $\mathrm{Ca}^{2+}$ currents might be modulated by neurotransmillers. These observations were first made in cardiac muscle fibers of both amphibians and mammals in which it was found that the stimulation of $\beta$-receptors by adrenaline: and its

Received December 28, 1984; Revised February 26, 1985;

Accepted February 28, 1985

\footnotetext{
${ }^{1}$ This work was supported by grants from the Centre National de la Recherche Scientifique, France; from the Institut National de la Recherche Médicale et de la Santé, France; and from the Ministère de la Recherche et de la Technologie, France. L. C. was supported by a fellowship of the Scuola Normale Superiore, Pisa, Italy. We thank Dr. J. Bockaert for his collaboration in the biochemical experiments and Dr. P. Ascher for helpful discussions.

2 Present address: Istituto di Fisiologia, Università di Pisa, Via San Zeno 39, 56100 Pisa, Italy.

${ }^{3}$ Present address: Laboratoire de Biologie Cellulaire et Moléculaire, Centre d'Etudes Nucléaires de Grenoble, 38041 Grenoble Cedex, France.

${ }^{4}$ To whom reprint requests should be addressed.
}

agonists caused an increase of the plateau component of the action potential of the cardiac muscle fibers, resulting from an increase of the $\mathrm{Ca}^{2+}$ current (see Reuter and Scholz, 1977; Reuter, 1983; Tsien, 1983). This effect was found to be mimicked by the application of the cyclic $3^{\prime}, 5^{\prime}$-adenosine monophosphate (cAMP) and its analogues (see Tsien, 1977; Brum et al., 1983; Reuter et al., 1983) and by the injection of the catalytic unit of a CAMP-dependent protein kirlase (Osterrieder et al., 1982; Brum et al., 1983). More recently, patch clamp studies have shown that $\beta$-adrenergic stimulation of cardiac muscle cells evokes an increase of the average number of functional $\mathrm{Ca}^{2+}$ channels per cell (Reuter et al., 1983; Bean et al., 1984) and a slowing down of the time course of both the activation and the inactivation of these channels (Bean et al., 1984; Brum et al., 1984).

A different mechanism was found to be involved in transmitterinduced increases of the plateau phase of the $\mathrm{Ca}^{2+}$ spikes recorded in the cell body of identified molluscan neurons. In sensory neurons of Aplysia californica and in identified neurons of Helix aspersa, serotonin (5-hydroxytryptamine; 5 -HT) was found to elicit an increase of the plateau component of the somatic $\mathrm{Ca}^{2+}$ action potential which resulted from a decrease in $\mathrm{K}^{+}$conductance (Klein and Kandel, 1978, 1980; Paupardin-Tritsch et al., 1981). This effect of 5-HT was also found to be mimicked by cither the intraccllular injection of cAMP or by agents which increased the intracellular CAMP concentration (Klein and Kandel, 1978, 1980; Deterre et al., 1981, 1982). An increase of the plateau phase of the action potential of Aplysia neurons was also evoked by the intracellular injection of the catalytic unit of a CAMP-dependent protein kinase (Kaczmarek et al., 1980; Castellucci et al., 1982). In voltage-clamped Aplysia sensory neurons, Klein et al. (1982) demonstrated that 5-HT decreased a specific outward current which they named the S-current. Patch-clamp analysis of the same neurons also revealed that either 5-HT or cAMP elicited the closing of the same population of "background" $\mathrm{K}^{+}$ channels (Siegelbaum et al., 1982). The application of the catalytic unit of a CAMP-dependent protein kinase to inside-out membrane patches from the same neurons induced the closing of the same $\mathrm{K}^{4}$ channel population (Shuster et al., 1985). More recentiy, Boyle et al. (1984) have reported that 5-HT also evoked in the Aplysia sensory cells an increase in the intracellular $\mathrm{Ca}^{2+}$ concentration, which could be due to an increase in $\mathrm{Ca}^{2+}$ influx or to an alteration of either the uptake or the release of $\mathrm{Ca}^{2+}$ by its intracellular stores.

Neurotransmitters have also been shown to decrease the duration of the $\mathrm{Ca}^{2+}$ spikes recorded in the cell body of other neurons. In rat sympathetic neurons, noradrenaline decreases the duration of the $\mathrm{Ca}^{2+}$ spike recorded in their soma (Horn and McAfee, 1980; Galvan and Adams, 1982), and sirnilar effects were observed in chick embryo dorsal root sensory neurons in culture following the application of several neurotransmitters (noradrenaline, GABA, serotonin, dopamine, enkephalin, and somatostatin) (Dunlap and Fischbach, 1980; Canfield and Dunlap, 1984). The mechanism of the effects of 
noradrenaline in both the dorsal root sensory neurons and in the sympathetic ganglion neurons is the same and involves a decrease in $\mathrm{Ca}^{2+}$ current resulting from a decrease in $\mathrm{Ca}^{2+}$ conductance without apparent alteration of the $\mathrm{Ca}^{2+}$ current kinetics (Dunlap and Fischbach, 1980; Galvan and Adams, 1982). Muscarinic agonists have also been reported to decrease the plateau phase of the action potential of the cardiac muscle fibers (Giles and Noble, 1980; see Tsien and Siegelbaum, 1980). This effect appears to be associated with a $\mathrm{Ca}^{2+}$ conductance decrease (Hino and Ochi, 1980) and may involve cyclic $3^{\prime}, 5^{\prime}$-guanosine monophosphate (cGMP) as a second messenger (Trautwein et al. 1982).

In the present work, we have examined the effects of dopamine (DA), the main catecholamine present in the molluscan nervous system, on the $\mathrm{Ca}^{2+}$ action potential recorded in the cell body of a number of identified snail neurons. We have found that DA can either increase or decrease the $\mathrm{Ca}^{2+}$-dependent plateau of these spikes. The DA-induced increase of the $\mathrm{Ca}^{2+}$ spike plateau was found to result from a decrease of an outward current component similar to the S-current (Klein et al., 1982), i.e., from a cAMP-mediated decrease in $\mathrm{K}^{+}$conductance. Therefore this action of DA appears to be similar to the above described effect of 5-HT on the $\mathrm{Ca}^{2+}$ spike of Aplysia sensory neuron and on a group of identified snail neurons.

The DA-induced decrease of the $\mathrm{Ca}^{2+}$-dependent plateau of the somatic spike of some identified snail neurons was found to be due to a decrease in $\mathrm{Ca}^{2+}$ current resulting from a decrease in $\mathrm{Ca}^{2+}$ conductance. This DA effect did not appear to be associated with increases in the intracellular concentrations of CAMP, CGMP, or $\mathrm{Ca}^{2+}$.

Each of these two opposite actions of DA on the $\mathrm{Ca}^{2+}$ spike of snail neurons could be observed in different neurons, and independently from the other. However, in another group of neurons, both effects of DA could also be found in the same single identified cell. In such neurons, the DA-induced $\mathrm{Ca}^{2+}$ conductance decrease was the predominant effect on the somatic spike since DA was observed to decrease its plateau phase.

Some of these results were previously reported in preliminary form (Deterre et al., 1982; Gerschenfeld et al., 1984). Recently, Akopyan et al. (1984) have also reported the observation of a DA-induced decrease of $\mathrm{Ca}^{2+}$ conductance in neurons of the mollusc Lymnaea stagnalis.

\section{Materials and Methods}

This study was performed on a group of identified neurons of the visceroabdominal ganglionic mass of the snail Helix aspersa. The neurons (D2, E13, F1, and F5) were identified from one preparation to another by their pusition according to the ganglion maps established by Kerkut et al. (1975). In the experiments, the snail perioesophagic ganglionic ring was isolated and fixed inside a suitable plastic chamber. The glioconnective envelope of the ganglia was extensively removed under microscopic control. The preparation was bathed in a continuously circulating saline of the following composition (in millimolar concentration per liter): $\mathrm{NaCl}, 120 ; \mathrm{KCl}$, 2.5; $\mathrm{CaCl}_{2}, 6 ; \mathrm{MgCl}_{2}, 3.5$; and HEPES, 10, $\mathrm{pH} 7.4$. The bath was connected to earth through an agar bridge.

The identified neurons were voltage clamped using a two-microelectrode system. The pipettes were filled with $3 \mathrm{M} \mathrm{KCl}$ and had resistances of 1 to 5 megohms. The transmembrane voltages and the clamping currents were recorded simultaneously on a Tektronix oscilloscope, a Gould pen recorder, and a Racal 4 magnetic tape recorder.

In some experiments the $1-V$ curves were obtained by holding the neuron membrane potential at the resting level $(-50 /-55 \mathrm{mV})$ and then depolarizing the cell using pulses of either 30 to $40 \mathrm{msec}$ or $1 \mathrm{sec}$ in duration. In tracing the $\mathrm{I}-\mathrm{V}$ curves for the $\mathrm{Ca}^{2+}$ currents, the current responses to equivalent hyperpolarizing pulses were added to cancel linear leakage.

in other experiments, the $\mathrm{I}-\mathrm{V}$ curves were obtained from neurons in which the membrane potential was held at $+10 \mathrm{mV}$. The membrane potential was then stepped by using 1-sec-duration voltage jumps, either in the hyperpolarizing direction (down to $-90 \mathrm{mV}$ ) or in the depolarizing direction (up to $+30 /+40 \mathrm{mV}$ ).

Dopamine and 5-HT were applied to the nes urons from single micropipettes the tips of which were placed near the cell membrane under microscopic control. The transmitters were ejected either by iontophoretic currents or by pressure. The iontophoretic pipettes were filled with eithor a $0.1 \mathrm{M}$ aqucous solution of dopamine chloride or a saturated aqueous solution of 5 -HTcreatinine sulfate, while the pipettes for pressure application were filled with a $1 \mathrm{~mm}$ solution of the transmitters in saline. In other cases DA was dissolved in the saline and applied through the circulating system.

EGTA, CAMP, and CGMP were injected intracellularly from single micropipettes by pressure or iontophoretically by passing appropriate currents between the barrels of double microelectrodes. In the latter case, one of the barrels was filled with aqueous solutions of $0.25 \mathrm{M} \mathrm{K}$-EGTA or $0.1 \mathrm{M}$ CAMP monosodium salt or CGMP monosodium salt, and the other barrel with $3 \mathrm{M}$ $\mathrm{KCl}$. In the case of pressure injections the three agents were dissolved in saline

The extracellular ionic concentration was modified in many experiments: $\mathrm{NaCl}$ was replaced by Tris- $\mathrm{Cl}$ or sucrose, and the extracellular $\mathrm{Ca}^{2+}$ concentration was totally replaccd by cither $\mathrm{Mg}^{2+}, \mathrm{Ba}^{2+}$, or $\mathrm{Co}^{2+}$. The latter two divalent cations were sometimes simply added to the saline. Tetraethylammonium (TEA) chloride was added to the saline by substituting for an equimolar amount of NaCl. Telrodotoxir (TTX), 4-aminopyridine (4-AP), EGTA, and some DA antagonists were dissolved in the circulating saline. Forskolin was first dissolved in absolute alcohol to prepare a $20 \mathrm{~mm}$ stock solution and then was diluted in the saline.

Nystatin experiments. These experiments were performed following the protocol established by Tillotson (1979). The neurons were first bathed for $30 \mathrm{~min}$ in a "Cs${ }^{+}$-loading" solution containing (in millimolar concentration per

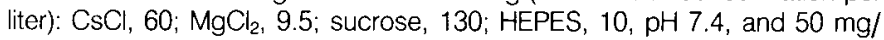
liter of nystatin. The preparation was then washed in the same solution without nystatin for another $30 \mathrm{~min}$. After this, the neurons were bathed in a solution containing (in millimolar concentration per liter): $\mathrm{NaCl}$ or Tris- $\mathrm{Cl}, 120$; $\mathrm{CsCl}, 5 ; \mathrm{MgCl}^{2+}, 3.5 ; \mathrm{BaCl}_{2}, 6$; and HEPES, $10, \mathrm{pH} 7$. In these experiments the micropipettes for recording voltage and current were always filled with 1 $\mathrm{M} \mathrm{CsCl.}$

Biochemical experiments. The assay of the adenylate cyclase activity was performed on isolated single identified snail neurons using a modification of the method that Imbert et al. (1975) initially devised for assaying the enzyme in isolated nephrons. The neurons were isolated from the ganglia by pulling their axons at a point located beyond their axon hillock. The cells isolated in this manner were placed in cold saline, aspirated with a saline aliquot inside a fine polyethylene tubing, and transported to the well of an excavated glass slide kept at $0^{\circ} \mathrm{C}$. The saline was removed under microscopic control and was replaced by $0.5 \mu \mathrm{l}$ of a solution containing: $100 \mathrm{mM}$ Tris- $\mathrm{HCl}(\mathrm{pH} 7.2), 1$ $\mathrm{mM}\left[{ }^{3} \mathrm{H}\right] \mathrm{cAMP}(0.02 \mu \mathrm{Ci}), 20 \mathrm{~mm}$ creatine phosphate, $0.3 \mathrm{mM}$ ATP, $0.25 \mathrm{~mm}$ EDTA, $0.1 \mathrm{~mm}$ GTP, $5 \mathrm{~mm} \mathrm{MgSO}_{4}$, and $1 \mathrm{mg} / \mathrm{ml}$ of creatine kinase. To allow the penetration of the substrates, the cell membranes were punctured using
A

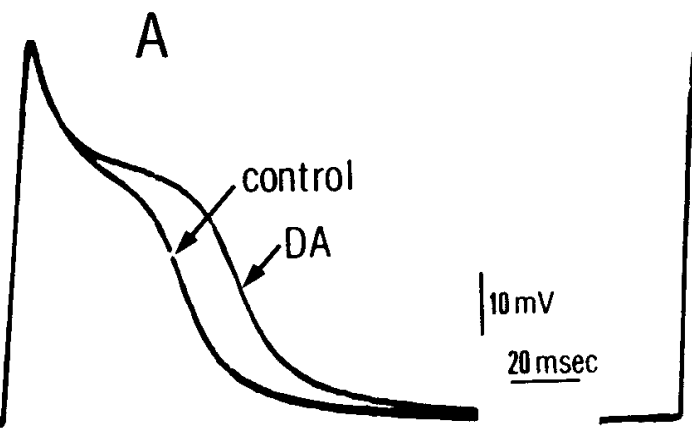

B

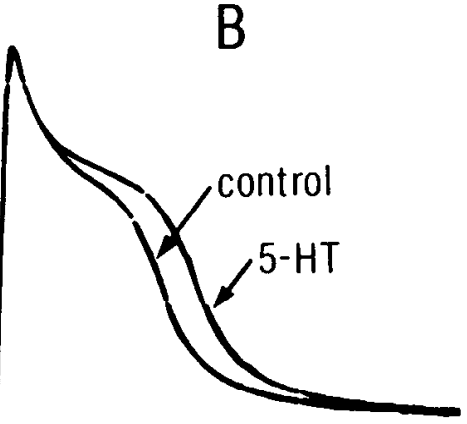

Figure 1. Both DA and 5-HT increase the amplitude of the spikc platcau of an E13 neuron bathed in a saline containing $30 \mathrm{~mm}$ TEA. A, Superimposed recordings of two action potenlials, in the absence (control) and in the presence of $20 \mu \mathrm{M}$ DA. $B$, Superimposed recordings of two action potentials obtained in the same cell, in the absence (control) and in the presence of $10 \mu \mathrm{M} 5-\mathrm{HT}$. 
two needles and the incubation was then started by adding $1.5 \mu l$ of the medium described above containing 2 to $3 \mu \mathrm{Ci}$ of $\left[\alpha-{ }^{32}\right.$ P]ATP and, when necessary, 100 to $500 \mu \mathrm{M} \mathrm{DA}$. Each slide was tightly covered and incubated for $30 \mathrm{~min}$ at $30^{\circ} \mathrm{C}$. At the end of the incubation period, the reaction was stopped by adding another solution containing $200 \mu \mathrm{l}$ of Tris- $\mathrm{HCl}(\mathrm{pH} 7.4), 5$ $\mathrm{mM}$ ATP, $5 \mathrm{~mm}$ CAMP, and $10 \mu \mathrm{g} / \mathrm{ml}$ of sodium lauryl sulfate. $\left[\alpha^{32} \mathrm{P}\right] \mathrm{cAMP}$ was isolated as previously described by Bockaert et al. (1976). To measure the adenylate cyclase activity in unstimulated cells, more than $200 \mathrm{cpm}$ were always counted, the blank value being less than $40 \mathrm{cpm}$. The values given in Table 1 are the means for 10 cells of the same identified class.

\section{Results}

DA-induced increase of the plateau phase of the calcium spike in snail neurons E13 and F1. Figure 1 shows the effects of a short extracellular application of DA and 5-HT on the action potential recorded in the soma of an E13 neuron bathed in a saline containing $30 \mathrm{~mm}$ TEA. Dopamine, like 5-HT (see Klein and Kandel, 1980; Paupardin-Tritsch et al., 1981), evoked an increase of the plateau phase of the $\mathrm{Ca}^{2+}$ spike. No attenuation of this DA eftect on the action potential was observed even if the application was prolonged for 10 to $20 \mathrm{~min}$ and regardless of the application method used.

Since it was already known that in those molluscan neurons in which 5-HT induced the increase of $\mathrm{Ca}^{2+}$ spike plateau, 5-HT also evoked a cAMP-mediated decrease of $\mathrm{K}^{+}$conductance, we explored whether DA elicited similar effects on cells E13 and F1. In voltageclamped cells, when the membrane potential was stepped from a holding level of $-50 /-55 \mathrm{mV}$ to $0 /+10 \mathrm{mV}$ by depolarizing pulses of 30 msec duration, a complex current was recorded, composed of an inward $\mathrm{Na}^{1} / \mathrm{Ca}^{2-1}$ component followed by a rather large outward current. The outward current could be better examined using prolonged depolarizing pulses ( 1 to $2 \mathrm{sec}$ ). An important part of the outward current thus recorded corresponded to the different $\mathrm{K}^{+}$ currents previously described in molluscan neurons: $I_{D R}$, the $\mathrm{K}^{+}$ current associated with delayed reactification; $I_{A}$, an early transient $\mathrm{K}^{+}$current; $I_{C}$, the $\mathrm{Ca}^{2+}$-dependent $\mathrm{K}^{+}$current (see reviews by $\mathrm{D}$. J. Adams et al., 1980; Adams, 1982); and the S-current (Klein et al., 1982).

To analyze separately the inward and outward currents of cells $E 13$ and $F 1$, the ionic composition of the extracellular medium was modified and some channel-blocking agents were added to the saline. In the experiment of Figure 2 such procedures were used to analyze in cell $F 1$ the effects of DA on either the isolated $\mathrm{Ca}^{2+}$ current or the TEA-resistant outward current.

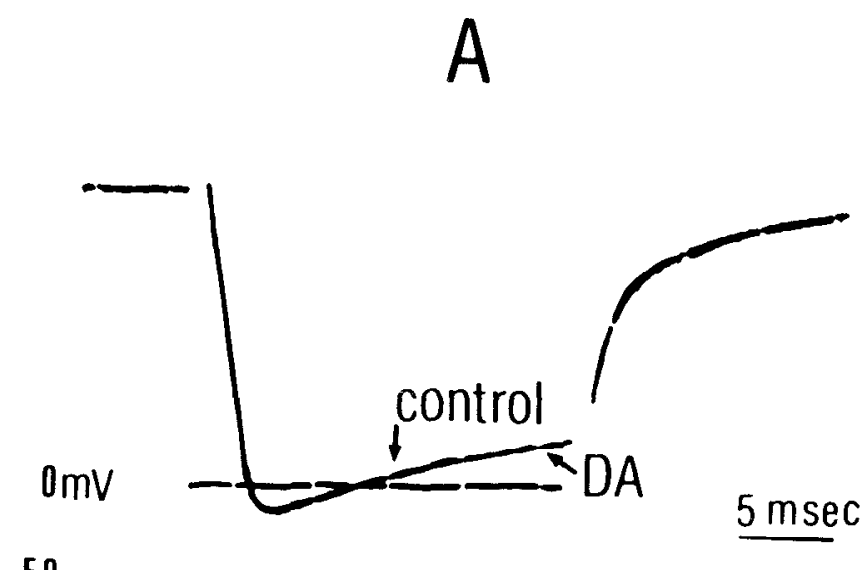

$-50$

\section{$6 \mathrm{Ba} 30 \mathrm{TEA}$}

In Figure $2 A$, the $\mathrm{Ca}^{2+}$ inward current component was separated from the other current components and facilitated by replacing with $\mathrm{Ba}^{2+}$ the extracellular $\mathrm{Ca}^{2+}$ content of a saline containing both $5 \mu \mathrm{M}$ TTX and 30 mM TEA (see Hagiwara and Byerly, 1981). The addition of 10 to $25 \mu \mathrm{M}$ DA to this modified saline elicited no alteration of the inward current of cell F1 (Fig. $2 A$ ). Indced, the trace of Figure $2 A$ actually corresponds to two superimposed recordings of the inward current obtained in the presence and in the absence of DA in the bath. In contrast, DA decreased the outward current. Figure $2 B$ illustrates the outward current elicited by a long depolarizing pulse in the same $\mathrm{F} 1$ cell bathed in a saline containing $30 \mathrm{mM}$ TEA. The application of $10 \mu \mathrm{M}$ DA evoked a decrease of the outward current, and this effect of DA resembles that of 5-HT on the Aplysia sensory neurons (Klein et al., 1982).

Figure 3 illustrates another experiment on an F1 cell, directed to identify the ionic nature of the outward current component decreased by DA. During the entire experiment, the bathing saline contained $30 \mathrm{~mm}$ TEA. In Figure $3 A$ the membrane potential was initially held at $-70 \mathrm{mV}$ and stepped by depolarizing pulses to $+10 \mathrm{mV}$. In these conditions, the early peak component of the outward current (Fig. $3 A-a$ ) disappeared when $1 \mathrm{mM}$ 4-AP was added to this medium (Fig. $3 A-b)$. The current component blocked by $4-A P$ in the presence of TEA probably corresponded in large part to $I_{A}$. Nevertheless, the DA application in the presence of both TEA and 4-AP was still able to evoke a decrease in amplitude of the outward current (Fig. $3 A-C$ ). In Figure 3B, 4-AP was removed from the bath and the holding potential was set at $-50 \mathrm{mV}$ for the rest of the experiment. Then, when the membrane potential was stepped to $+10 \mathrm{mV}$ the peak current previously blocked by 4-AP was less prominent (Fig. $3 B-a$ ). In these conditions, the replacement of the extracellular $\mathrm{Ca}^{2+}$ content of the saline by $\mathrm{Mg}^{2+}$ evoked a significant reduction of the amplitude of the outward current (Fig. 3B-b) due to the block of TEA-resistant, $\mathrm{Ca}^{2+}$-dependent components. However, DA was still found to elicit a marked depression of the outward current (Fig. 3B-C). In contrast, when the extracellular $\mathrm{Ca}^{2+}$ was replaced by either $\mathrm{Co}^{2+}$ (Fig 3C) or $\mathrm{Ba}^{2+}$ (fig. 3D), the amplitude of the outward current was markedly decreased and the addition of DA to the bath had no further effect (Fig. $3 C-\mathrm{C}$ and $\mathrm{D}-\mathrm{c}$ ); i.e., in these experiments both $\mathrm{Co}^{2+}$ and $\mathrm{Ba}^{2+}$ blocked, besides the $\mathrm{Ca}^{2+}$-dependent oulward current components, the DA-sensitive outward current component. With the exception of its sensitivity to these divalent cations, the current component suppressed by DA appeared to be similar to the S-current inactivated by 5-HT in Aplysia sensory neurons (Klein et al., 1982).

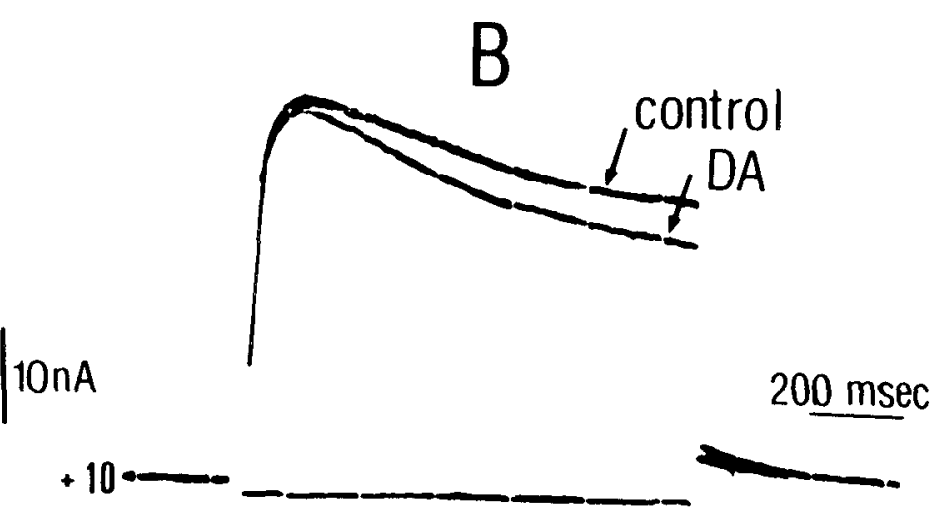

Figure 2. DA effects on the membrane currents of an F1 neuron. $A_{i}$ Voltage-clamp recordings from an $F 1$ cell in which the membrane potential held at $-50 \mathrm{mV}$ is stepped to $0 \mathrm{mV}$ using pulses of $25 \mathrm{msec}$ duration. The unique trace actually corresponds to two superimposed recordings of the inward current obtained in the absence and in the presence of $10 \mu \mathrm{M}$ DA in the extracellular medium. The inward current was isolated by bathing the preparation in a saline containing $5 \mu \mathrm{M} T T X$ and $30 \mathrm{mM}$ TEA in which $\mathrm{Ca}^{2+}$ was replaced with $\mathrm{Ba}^{2+} . B$, Outward current recordings from the same $\mathrm{F} 1$ neuron bathed in a saline containing $30 \mathrm{mM}$ TEA. The neuron was also held at $-50 \mathrm{mV}$ and the voltage was stepped to $+10 \mathrm{mV}$ using pulses of $1200 \mathrm{msec}$ duration. The application of $10 \mu \mathrm{M}$ DA decreased the amplitude of the outward current. 


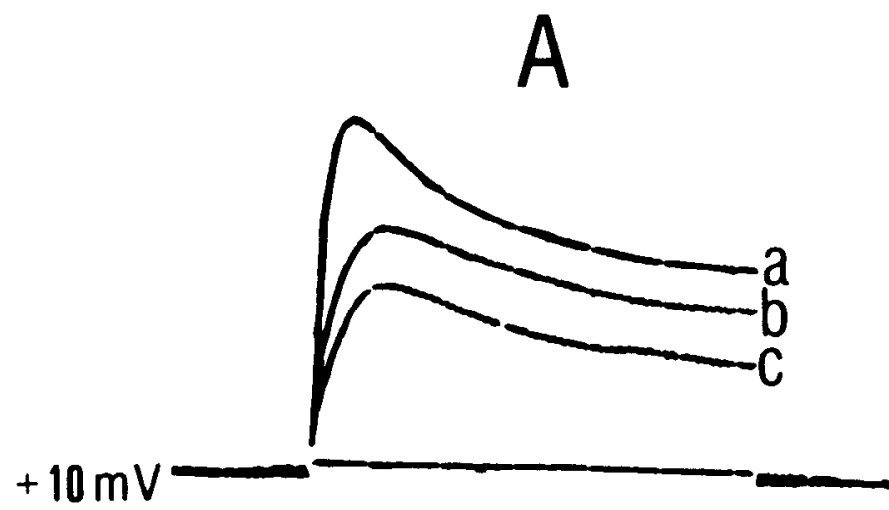

$-70$
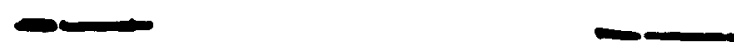

Q

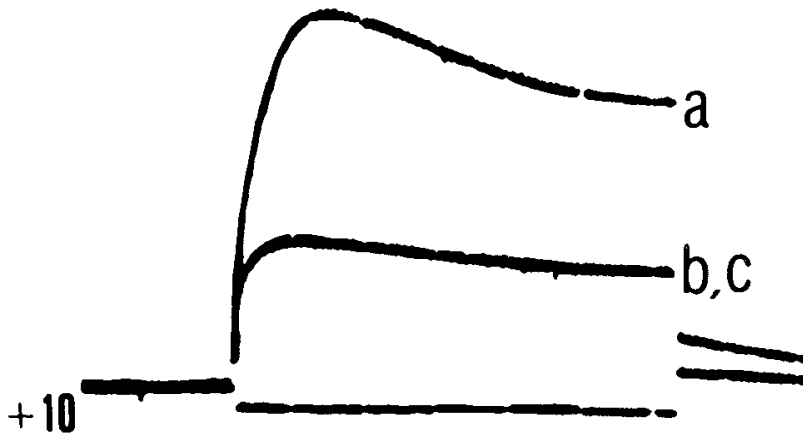

$-50$

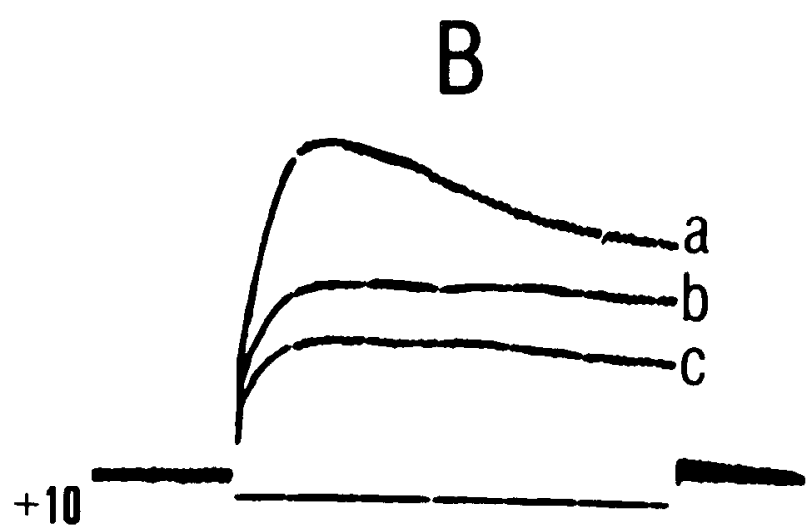

$-50-$

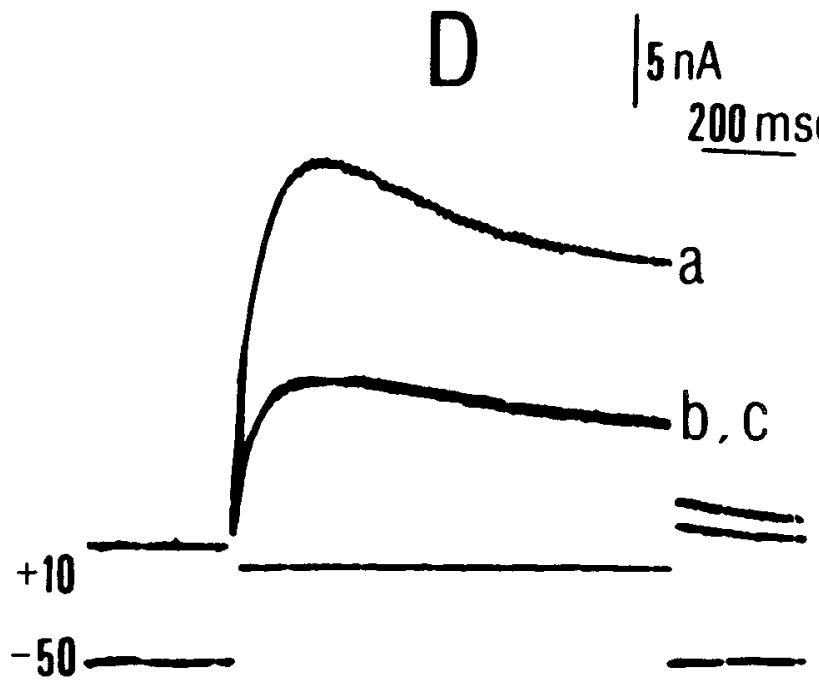

Figure 3. DA depresses an outward current component insensitive to both TEA and 4-AP. All of the recordings are from the same F1 neuron bathed in a saline containing $30 \mathrm{~mm}$ TEA. A, The neuron held at $-70 \mathrm{mV}$ was depolarized to $+10 \mathrm{mV}$ by pulses of $1200 \mathrm{msec}$ duration. $a$ : Control recording. $b$ : The addition of $1 \mathrm{mM}$ 4-AP to the medium blocks both the peak and a sustained component of the outward current. $\mathrm{c}$ : The addition fo $10 \mu \mathrm{M}$ DA in the presence of 4-AP still depresses the outward current. $B$, Recordings obtained after removing 4-AP from the extracellular medium. in the $\mathrm{F} 1 \mathrm{cell}$ held at $-50 \mathrm{mV}$ the potential is stepped to $+10 \mathrm{mV}$ using pulses of $1200 \mathrm{msec}$ duration. Notice that in these conditions the peak of the current is less prominent. $a$ : Control. $b$ : The $\mathrm{Ca}^{2+}$ content of the saline is replaced with $\mathrm{Mg}^{2+}$ and the TEA-resistant, $\mathrm{Ca}^{2+}$-dependent outward currents are blocked. $\mathrm{C}$ : The application of $10 \mu \mathrm{M} \mathrm{DA}$ still depresses the remaining outward current recorded in a $\mathrm{Ca}^{2+}$-free, TEA-containing extracellular medium. $C$, The control TEA-resistant outward current (a) is recorded as in $B$. The replacement of the $\mathrm{Ca}^{2+}$ content of the saline with $\mathrm{Co}^{2+}$ blocks an important part of the outward current $(b)$. Further addition of 10 $\mu \mathrm{M}$ DA to this medium has no effect $(C)$. D. Outward current recorded as in $C$. a: Control current recorded in a TEA-containing saline. b: Replacement of the extracellular $\mathrm{Ca}^{2+}$ with $\mathrm{Ba}^{2+}$ blocks an important part of the outward current. c: Application of $10 \mu \mathrm{M} \mathrm{DA}$ has no effect on the remaining outward current.

An important finding of the previous work on the 5-HT-induced decrease in $\mathrm{K}^{+}$current was the observation in the patch-clamp experiments of Siegelbaum et al. (1982) that, in the Aplysia scnsory neurons held at membrane potentials near the zero level, the $\mathrm{K}^{+}$ channels closed by 5 -HT constituted the main population of open channels observed. This might account for our own previous observation in identified snail neurons (Deterre et al., 1982) that the $\mathrm{K}^{+}$ conductance inactivated by 5 -HT could also be studied in voltageclamp conditions, holding the neuron membrane potential for long periods of time at +10 or $+20 \mathrm{mV}$. In these conditions, the application of 5-HT onto snail cells E13 and F1 elicited an inward current which resulted from a cAMP-dependent decrease in a $\mathrm{K}^{+}$conductance different from the conductances generating $I_{D R}, I_{A}$, and $I_{C}$ (Deterre et al., 1981; Paupardin-Tritsch et al., 1981), and this 5-HTinduced inward current probably corresponded to the closing of the main population of channels open at such potential levels. DA was also found to evoke a similar inward current. The recordings of Figure 4 were obtained from an F1 neuron bathed in normal saline, in which the membrane potential was held at $+10 \mathrm{mV}$. Successive iontophoretic applications of either DA or 5-HT evoked inward currents showing similar latencies and time courses (Fig. 4A). These inward currents were not affected when the $\mathrm{NaCl}$ of the saline was replaced by Tris-Cl or sucrose (not shown). In contrast, the amplitude of these responses was somewhat decreased when the $\left(\mathrm{Ca}^{2+}\right)_{0}$ was replaced by $\mathrm{Mg}^{2+}$. However, even if $1 \mathrm{~mm}$ EGTA was added to a $\mathrm{Ca}^{2+}$-free saline and the cell was kept in such medium for more than $1 \mathrm{hr}$, the DA- and 5-HT-induced inward currents were not blocked. The replacement of the extracellular $\mathrm{Ca}^{2+}$ ions by either $\mathrm{Co}^{2+}$ or $\mathrm{Ba}^{2+}$ induced an inward current by itself (see Paupardin-Tritsch et al., 1981) and then the application of either DA or 5-HT became ineffective (see below).

Bath application of 10 to $50 \mu \mathrm{M}$ DA to an F1 neuron held at +10 $\mathrm{mV}$ induced an inward current that reached a maximal saturating amplitude (Fig. 4B). This DA-induced current persisted without desensitizing for as long as DA was present in the extracellular medium. A similar current saturation was also observed when 10 to $50 \mu \mathrm{M}$ 5-HT was applied, and in both cases, this saturation corresponded to the maximal closing of the $\mathrm{K}^{+}$channel population (see 
Siegelbaum et al., 1982). Indeed, in the presence of a responsesaturating concentration of DA, fur ther application of either DA or 5HT became completely ineffective (Fig. $4 B$ ).

Like DA, intracellularly injected CAMP evoked an inward current in the $\mathrm{E} 13$ and $F 1$ neurons when their membrane potential was held at $+10 \mathrm{mV}$. Figure $5 \mathrm{~A}$ shows that this CAMP-induced inward current had a time course rather similar to that of the current induced by DA but that its latency was much shorter. When bath-applied DA evoked a saturating inward current, further intracellular injections of CAMP became ineffective (Fig. 5B).

The same observations could also be made when the increase of the intracellular cAMP concentration was obtained by other methods. These consisted of either stimulating adenylate cyclase or inhibiting phosphodiesterase. Thus, the application of $20 \mu \mathrm{M}$ forskolin, a potent adenylate cyclase stimulator (Seamon and Daly, 1981), to cells E13 and $F 1$ evoked a saturating inward current during which DA application became ineffective (Fig. 5C). Similar results were observed when bathing the $\mathrm{E} 13$ and $\mathrm{F} 1$ neurons in $100 \mu \mathrm{M}$ isobutylmethylxanthine (BMX), a phosphodiesterase inhibitor (Fig. 5D).

Table I summarizes the results of the experiments of biochemical assay of the adenylate cyclase activity in single isolated E13 and F1 snail neurons (see also Deterre et al., 1982). These results indicate that DA induced a 2 -fold stimulation of the enzyme activity of these cells.

The I-V relations of Figure 6 further indicate that DA and CAMP do affect the same ionic channels of the F1 neuron membrane. In this graph, the normalized values of the net currents elicited by the application of either DA or CAMP to an F1 cell were plotted against the levels at which the membrane potential was stepped from a holding level of $+10 \mathrm{mV}$ using pulses of $1 \mathrm{sec}$ duration. It is evident that the value of the net currents induced by DA (Fig. 6 , circles) and cAMP (Fig. 6, squares) are fitted by the same I-V curve, which shows that both DA- and CAMP-induced currents reversed at -50 $\mathrm{mV}$. The existence of such a negative reversal potential in the case of an inward current was a confirmation that the mechanism generating the currents was a decrease in cationic conductance. The

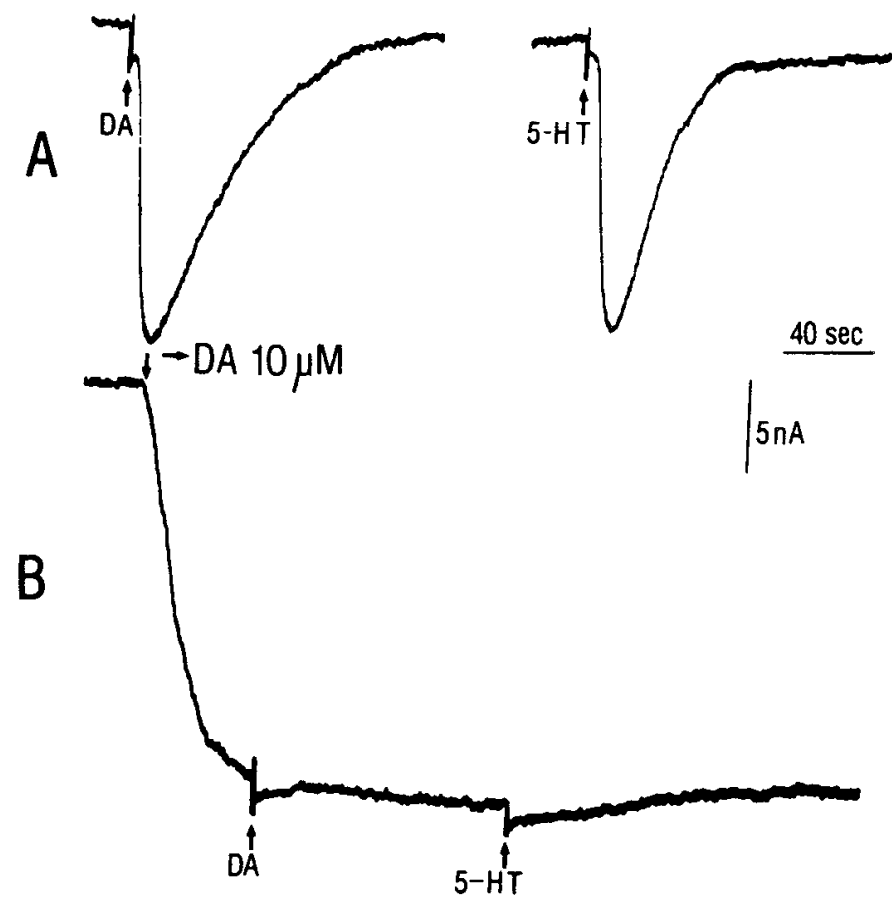

Figure 4. A, lontophoretic application of DA and 5-HT onto an F1 neuron held at $+10 \mathrm{mV}$ evokes inward currents of similar time course. $B$, Bath application of $20 \mu \mathrm{M}$ DA evokes a saturating inward current and further iontophoretic application of either DA or 5-HT becomes ineffective (see the text).
$A$
$B$
C
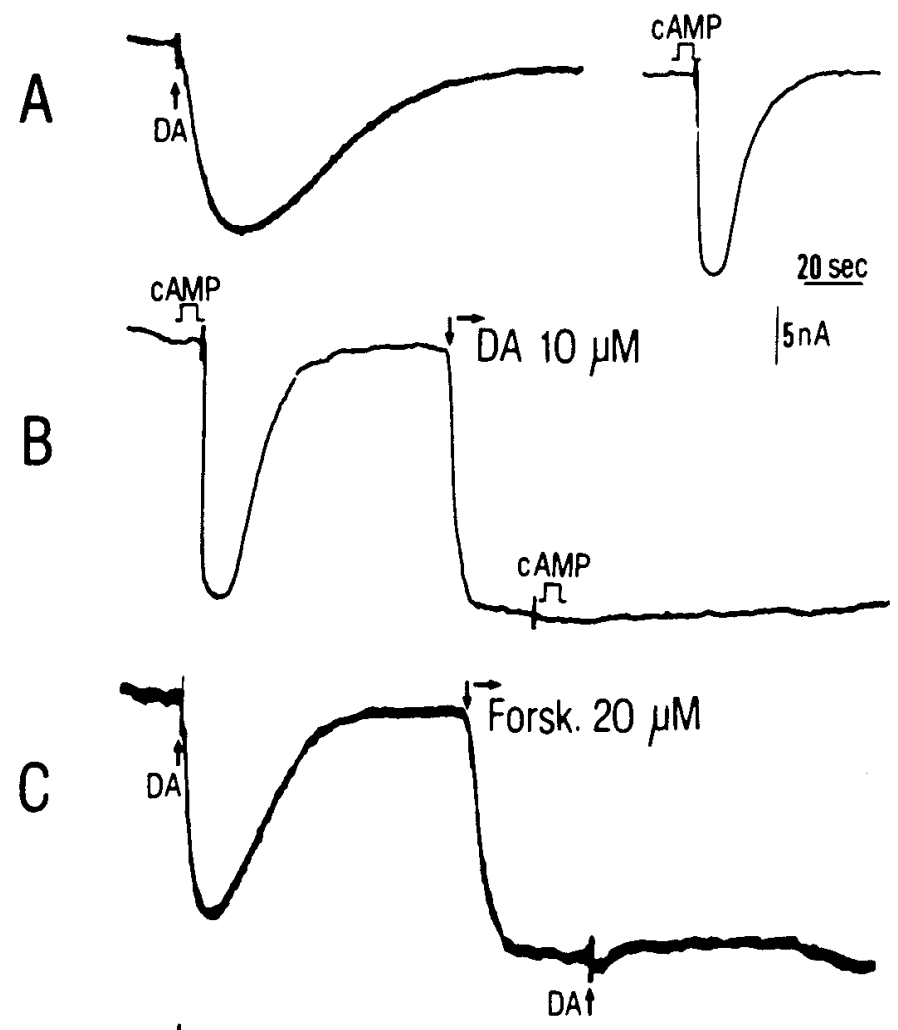

D

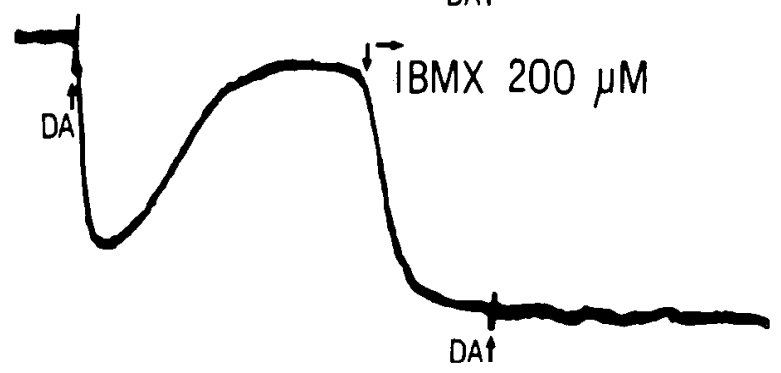

Figure 5. A, The iontophoretic application of DA and the intracellular pressure injection of cAMP evoke inward currents of similar characteristics in an F1 neuron held at $+10 \mathrm{mV}$. B, The intracellular injection of cAMP becomes ineffective in the presence of a saturating inward current elicited by the bath application of $10 \mu \mathrm{M} \mathrm{DA}$. The iontophoretic application of DA also becomes ineffective in the presence of a saturating inward current elicited by the application of $20 \mu \mathrm{M}$ forskolin (C) or $200 \mu \mathrm{M}(D)$ (see the text).

TABLE I

Adenylate cyclase activity in identified snail neurons CAMP values are means \pm SEM for 10 different neurons of the same class. Observed increases are given as porcentages of the basal activity.

\begin{tabular}{cccc}
\hline Neuron & $\begin{array}{c}\text { Base cAMP } \\
\left(10^{2} \mathrm{fmol} / 30 \mathrm{~min} / \text { cell }\right)\end{array}$ & $\begin{array}{c}\text { DA } \\
(100 \mu \mathrm{M})\end{array}$ & Increase \\
\hline F1 & $59 \pm 6$ & $141 \pm 15^{b}$ & $150 \%$ \\
$\mathrm{E} 13$ & $97 \pm 10$ & $198 \pm 28^{b}$ & $100 \%$ \\
$\mathrm{D} 2^{\circ}$ & $61 \pm 9$ & $58 \pm 7$ & 0 \\
\hline
\end{tabular}

${ }^{2}$ From Deterre et al. (1982).

${ }^{n} p<0.001$

sensitivity (not illustrated) of the reversal potential to the alteration of $\left(\mathrm{K}^{+}\right)_{0}$, but not to the changes in $\left(\mathrm{Na}^{+}\right)_{0}$ or $\left(\mathrm{Cl}^{-}\right)_{0}$, suggests that the DA- and CAMP-induced currents mainly involved a decrease in $\mathrm{K}^{+}$ conductance. However, the reversal potential of the net currents evoked by both agents did not exactly correspond to the value of the equilibrium potential for $\mathrm{K}^{+}$ions, $E_{K}$, of snail neurons bathed in normal saline, which is approximately $-75 \mathrm{mV}$. This difference 


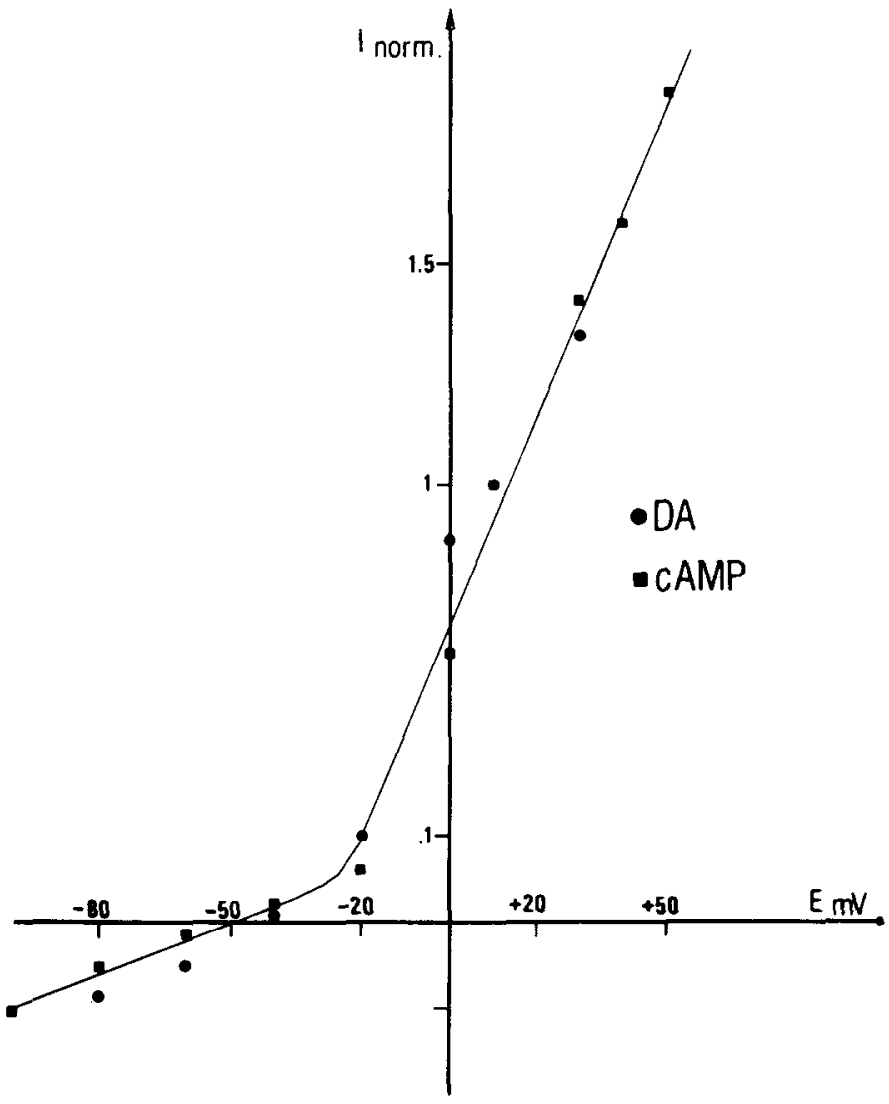

Figure 6. I-V curves relating the normalized net currents evoked by the iontophoretic applications of DA (O) and the intracellular pressure injections of CAMP ( $\square$ ) in an F1 neuron bathed in saline containing $30 \mathrm{~mm}$ TEA. The steady-state I-V curves were first obtained by stepping the voltage from the holding level $(+10 \mathrm{mV})$ to -90 and +50 by using 1 -sec-duration pulses and measuring the current at the end of the pulses. The net currents evoked by either DA or CAMP were obtained by subtracting the steady-state I-V curves obtained in the presence of the two agents from the control steady-state I-V curves. between $E_{K}$ and the reversal potential of the net currents evoked by the two agents may be due either to other effects of these agents on the membrane conductance of the F1 neuron (see Ascher, 1972; Swann and Carpenter, 1975; D. J. Adams et al., 1980; Akopyan et al., 1980; Hockberger and Connor, 1983; Chesnoy-Marchais, 1984; Swandulla and Lux, 1984), or to an extracellular accumulation of $\mathrm{K}^{+}$ ions resulting from the fact that the cell was held at $+10 \mathrm{mV}$ or from a lack of selectivity of the channels.

DA-induccd decrease of the calcium component of the action potential of neuron D2. In the D2 neuron the effect of DA application on the action potential was opposite to that observed in the cells $\mathrm{E} 13$ and $\mathrm{F} 1$, described in the previous sections.

Figure $7 \mathrm{~A}$ illustrates that, in a D2 neuron bathed in a TEAcontaining extracellular medium, DA application either from an iontophoretic micropipette or through the circulating saline (at 1 to 10 $\mu \mathrm{M}$ concentration), decreased the amplitude of the plateau phase of the spike recorded in the cell body. A voltage-clamp analysis of the transmembrane currents in the same neuron (Fig. 7, $B$ and $C$ ) revcaled that the mechanism involved in this action of DA was completely different from that observed in neurons E13 and F1. Thus, when the $\mathrm{D} 2$ cell was bathed in a medium in which $\mathrm{Ca}^{2+}$ was replaced by $\mathrm{Mg}^{2+}$ and to which $30 \mathrm{~mm}$ TEA was added, the application of a 1 -sec voltage step from a holding level of $-50 \mathrm{mV}$ to $0 \mathrm{mV}$ evoked an outward current. The application of $10 \mu \mathrm{M} \mathrm{DA}$ did not alter this outward current: the trace in Figure $7 \mathrm{C}$ actually corresponds to the superimposed recordings of the outward current in the absence and in the presence of DA. In contrast, when the membrane currents of cell D2 were recorded in a TTX/TEA-containing saline in which $\mathrm{Ca}^{2+}$ was replaced by $\mathrm{Ba}^{2+}$, bath application of $10 \mu \mathrm{M}$ DA evoked a 30 to $40 \%$ decrease of the inward current and of the inward tail currents (Fig. 7B, arrows).

To confirm that DA specifically decreased the $\mathrm{Ca}^{2+}$ current in cell D2 and that such effect did not involve any modification of a hidden outward current component, a series of experiments was performed using the antibiotic nystatin to exchange completely the intracellular $\mathrm{K}^{+}$content by $\mathrm{Cs}^{+}$(see Tillotson, 1979). Figure 8 corresponds to one of these experiments in which, after incubating a D2 neuron in the $\mathrm{Cs}^{+}$-loading solution containing nystatin (see "Materials and Methods"), the nystatin-containing solution was removed and the

$$
\text { A }
$$

B

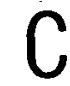

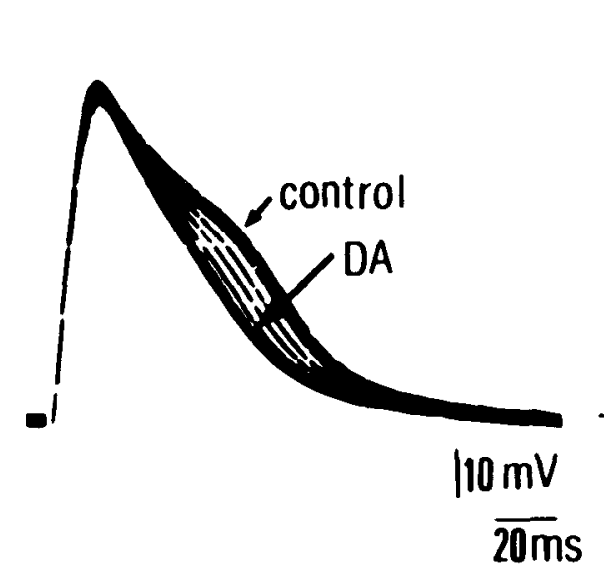
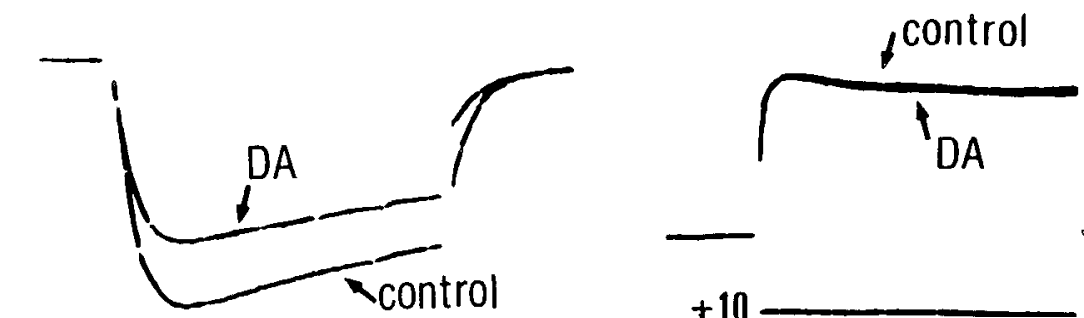

\section{Ca 30 TEA}

$6 \mathrm{Ba}, 30$ TEA

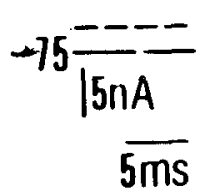

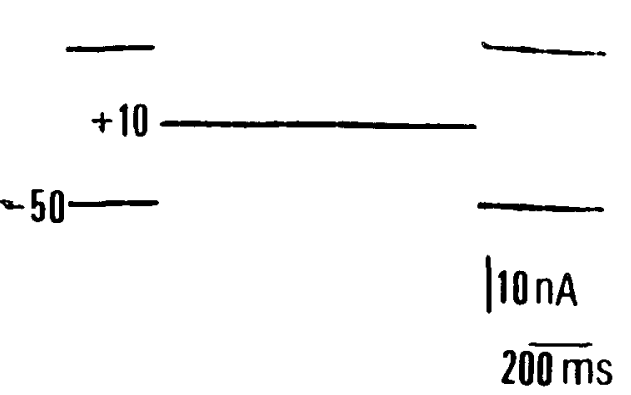

Figure 7. DA-induced decrease of the $\mathrm{Ca}^{2+}$-dependent plateau and of the inward current in neuron D2. A, Bath application of $10 \mu \mathrm{M}$ DA to a D2 cell bathed in a saline containing $30 \mathrm{~mm}$ TEA evokes a marked decrease of amplitude of the spike plateau. After the DA application the successive action potentials recorded are superimposed. $B$, Inward currents recorded after voltage-clamping the same D2 neuron bathed in a TEA-containing saline in which $\mathrm{Ca}^{2+}$ was replaced with $\mathrm{Ba}^{2+}$. The cell held at $-50 \mathrm{mV}$ is depolarized for $30 \mathrm{msec}$ to $0 \mathrm{mV}$ and then repolarized to $-75 \mathrm{mV}$, the potential level corresponding to $E_{K}$. In this condition the control current shows an inward tail current (arrow). The application of $10 \mu \mathrm{M}$ DA decreases the amplitude of both the inward current and the tail inward current. C. Outward current recorded in the same D2 cell recorded in a TEA-containing saline in which Ca ${ }^{2+}$ was rcplaced with $\mathrm{Mg}^{2+}$. The apparently unique trace corresponds to two superimposed recordings obtained in the absence and in the presence of a $10 \mu \mathrm{M}$ concentration of $\mathrm{DA}$ in the bathing saline. 

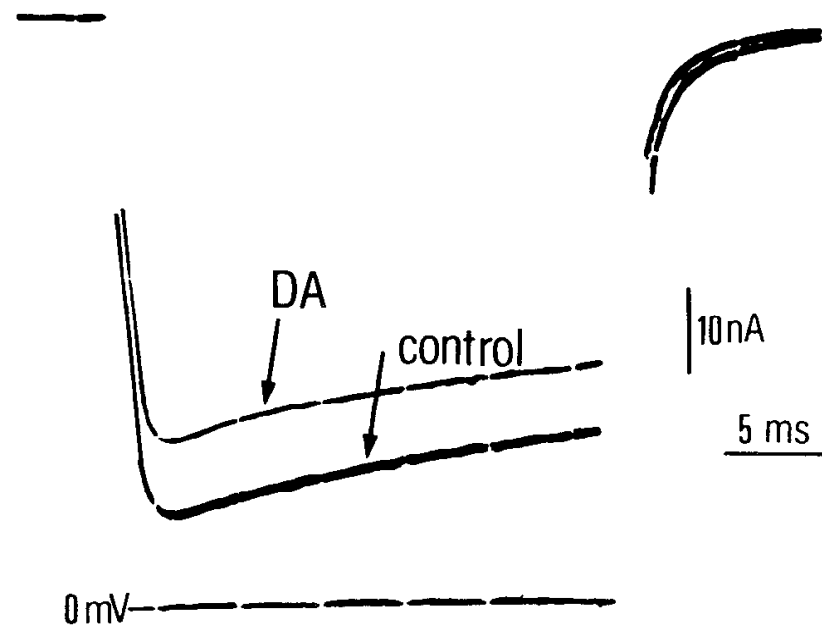

50 after nystatin treatment

Figure 8. Persistance of the DA-induced decrease of the inward current in a D2 neuron loaded with $\mathrm{Cs}^{+}$, after nystatin treatment. The cell is bathed in a saline in which $\mathrm{K}^{+}$was replaced with $\mathrm{Cs}^{+}$and $\mathrm{Ca}^{2+}$ was replaced with $\mathrm{Ba}^{2+}$.

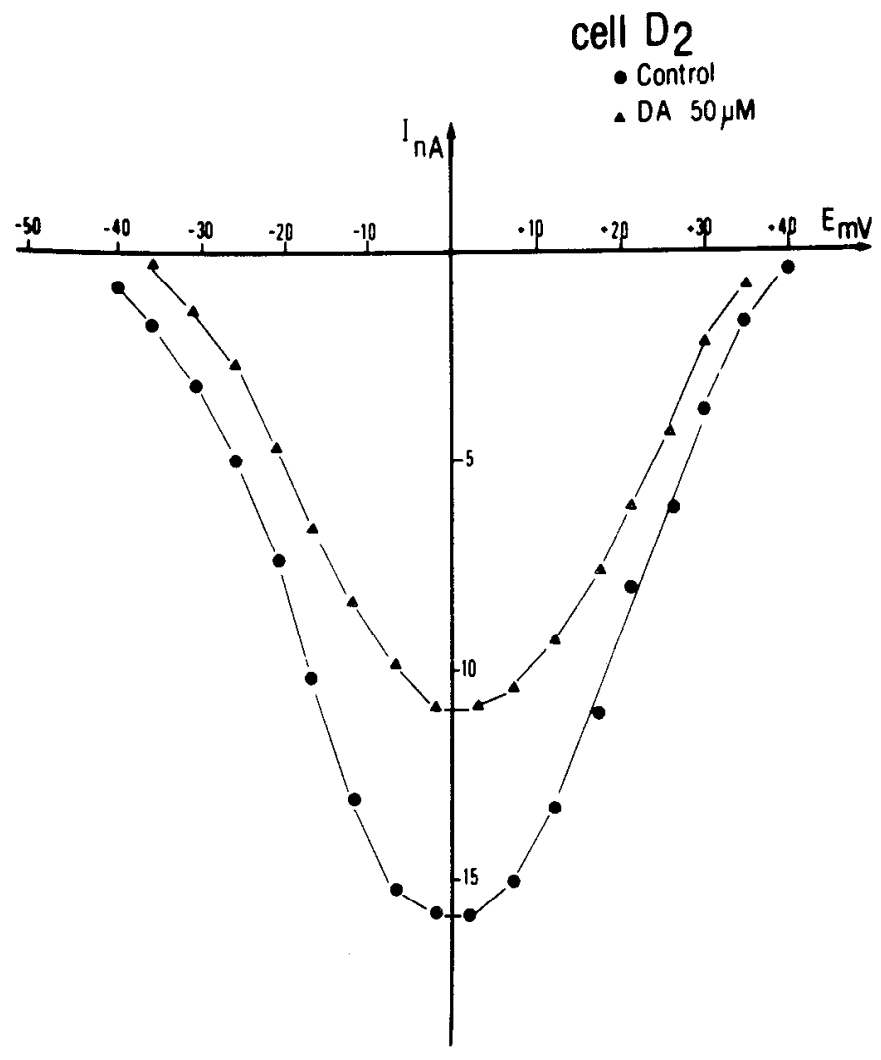

Figure 9. DA effect on the $\mathrm{I} V \mathrm{~V}$ curve obtained in a $\mathrm{D} 2$ neuron bathed in a TTX/TEA-containing saline in which $\mathrm{Ca}^{2+}$ was replaed with $\mathrm{Ba}^{2+}$. The maximum inward currents obtained in the absence (0) and in the presence $(\mathbf{A})$ of $50 \mu \mathrm{M} \mathrm{DA}$ in the extracellular medium were plotted against the values at which the potential was stepped. Both curves were corrected for linear leakage conductance.

cell was bathed in a $\mathrm{Cs}^{+}$-containing Tris saline in which $\mathrm{Ca}^{2+}$ had been replaced by $\mathrm{Ba}^{2+}$. The $\mathrm{Ca}^{2+}$ current recorded in such conditions (in which the only monovalent cation present inside and outside the cell was $\mathrm{Cs}^{+}$) also became markedly decreased by the addition of $10 \mu \mathrm{M}$ DA to the bath (Fig. 8, DA).

Attempts were then made to investigate the mechanism involved in the DA-induced modification of the $\mathrm{Ca}^{2+}$ current. Figure 9 illustrates $\mathrm{I}-\mathrm{V}$ curves relating the $\mathrm{Ca}^{2+}$ current amplitudes and the membrane potential at which they were recorded in a D2 cell bathed in a TTX/ TEA/Ba ${ }^{2}$-containing saline. These I-V curves were corrected by subtracting the leakage current. It is clear that DA decreased the $\mathrm{Ca}^{2+}$ current (Fig. 9, triangles) through all the range at which the D2 cell membrane potential was stepped. Moreover, the potential level at which the $\mathrm{Ca}^{2+}$ current became maximal either in the presence or in the absence of $50 \mu \mathrm{M} D A$ in the bath was the same, and the decrease induced by DA was maximal at such potential levels. In the voltage-clamp conditions of our experiments, we could not exclude the modification of the reversal potential of the $\mathrm{Ca}^{2+}$ current by DA (Fig. 9). However, such modification could not have been a substantial one (see, for instance, the calculations of Dunlap and Fischbach (1980) which predict that, to account for a $30 \%$ decrease in $\mathrm{Ca}^{2+}$ current, the shift of the reversal potential should be much more important than it appears in Fig. 9). Therefore, it can be concluded that the main effect of DA on the snail D2 neuron was to decrease the maximal $\mathrm{Ca}^{2+}$ conductance.

Other experiments were directed to explore whether an intracel. lular messenger intervened in the DA-induced decrease of the $\mathrm{Ca}^{2+}$ conductance. Three of these messengers have been involved in the intracellular control of the $\mathrm{Ca}^{2+}$ current: CAMP (see Reuter, 1983), cGMP (see Trautwein et al., 1982), and $\mathrm{Ca}^{2+}$ ions (see Tillotson, 1979; Eckert and Tillotson, 1981). The intracellular injection of either cAMP or cGMP in the D2 neuron affected neither the $\mathrm{Ca}^{2+}$ spike nor the membrane currents. Table I also shows that DA did not induce any alteration of the basal activity of the adenylate cyclase in single D2 cells (Deterre et al., 1982). Therefore, an increase in the intracellular concentration of either CAMP or cGMP does not appear to play a role in the DA-induced decrease of $\mathrm{Ca}^{2+}$ conductance.

Looking for a possible intervention of intracellular $\mathrm{Ca}^{2+}$, we have studied the effects of decreasing the intracellular $\mathrm{Ca}^{2+}$ concentration by injecting EGTA into the cell. In Figure $10 A$, the $\mathrm{Ca}^{2+}$ current of a $\mathrm{D} 2$ cell bathed in a TTX/TEA/Ba ${ }^{2+}$-containing medium was decreased by DA. After injecting EGTA inside the neuron for $30 \mathrm{~min}$, a marked increase of the amplitude of the $\mathrm{Ca}^{2+}$ current was observed. Such an effect of EGTA could be due either to a removal of $\mathrm{Ca}^{2+}$ channel inactivation resulting from the decrease in intracellular $\mathrm{Ca}^{2+}$ or to a block of a hidden $\mathrm{Ca}^{2+}$-dependent outward current component. Nevertheless, when DA was applied at the end of the EGTA injection pcriod, it induced a decrease of the $\mathrm{Ca}^{2+}$ current proportional to that observed in the control experiment (Fig. 10B). This therefore suggests that the DA-induced decrease of $\mathrm{Ca}^{2+}$ conductance is not mediated by an increase in intracellular $\mathrm{Ca}^{2+}$.

Composite effects of DA on the voltage-dependent currents of other snail neurons. The examples of neurons $E 13$ and $F 1$ on the one hand, and of the D2 neuron on the other hand, illustrate that DA can act by specifically decreasing one component of the membrane conductance. However, in other identified neurons in which DA evoked a decrease in the plateau phase of the somatic $\mathrm{Ca}^{2+}$ spike, DA showed more complex effects on the membrane currents.

This is illustrated in Figure $11 \mathrm{~A}$ which shows two superimposed recordings from a TEA-treated F5 neuron. The plateau phase of the action potential of this cell was markedly decreased in the presence of $10 \mu \mathrm{M}$ DA. Nevertheless, when the F5 neurons of different snail preparations were voltage clamped and their membrane currents analyzed, the results of DA application were surprising. As expected from previous experiments, in a saline in which $\mathrm{Ca}^{2+}$ was replaced with $\mathrm{Ba}^{2+}$ and $30 \mathrm{~mm}$ TEA was added, DA was found to induce a decrease in the $\mathrm{Ca}^{2+}$ current (Fig. 11B), resembling that seen in the D2 neuron. However, when the F5 neuron was bathed in a TEAcontaining saline in which $\mathrm{Ca}^{2+}$ was replaced by $\mathrm{Mg}^{2+}, \mathrm{DA}$ also was found to evoke a decrease of a TEA-resistant outward current similar to the $\mathrm{S}$ current (Fig. 11C). The steady-state voltage-clamp analysis of cell F5 also revealed that DA induced in this cell an inward current showing the same features as those described in cells E13 and F1. This inward current was also mimicked by cAMP. From these results we concluded that DA induced, in cell F5, both a CAMP-mediated 
A

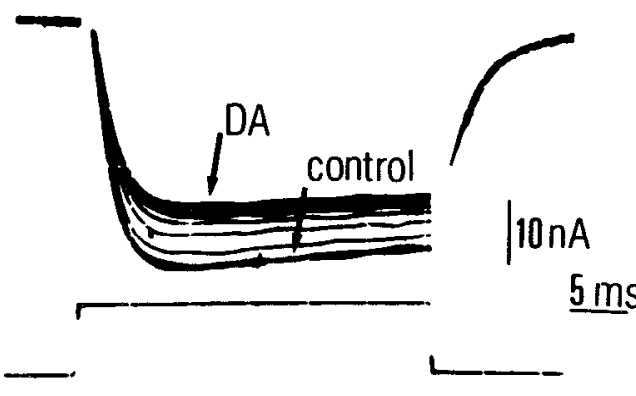

B

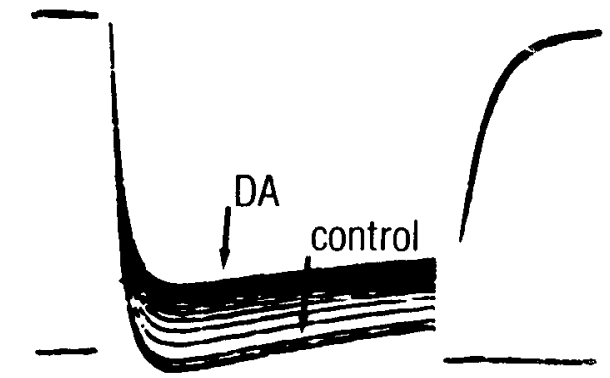

Figure 10. Intracellular injection of EGTA in cell D2. A, Superimposed recordings of the decreasing inward current following the application of $10 \mu \mathrm{M}$ DA. The D2 cell is bathed in a TTX/TEA/ $/ \mathrm{Ba}^{2+}{ }_{\text {-containing saline. } B \text {, Recording }}$ from the same cell after injecting EGTA intracellularly for $30 \mathrm{~min}$. The amplitude of the inward current is markedly increased, but the application of $10 \mu \mathrm{M}$ DA evokes a decrease of the inward current proportional to the effect re corded before the EGTA injection.

\section{after EGTA injection}

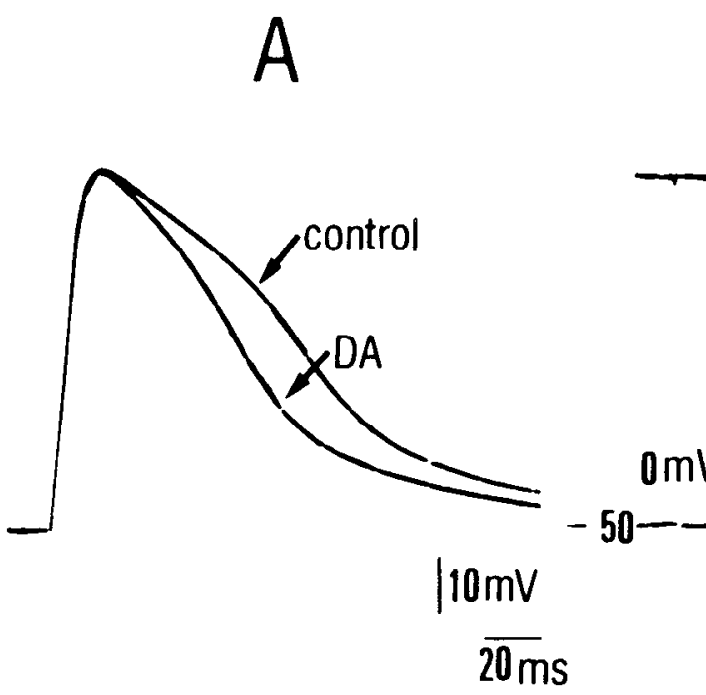

$6 \mathrm{Ca}, 30 \mathrm{TEA}$
B

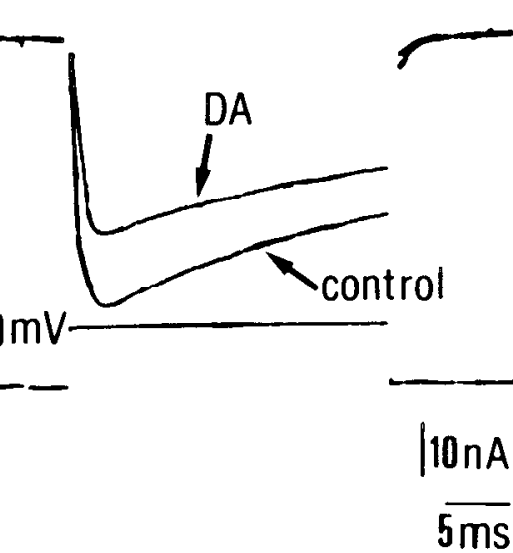

6Ba, 30 TEA
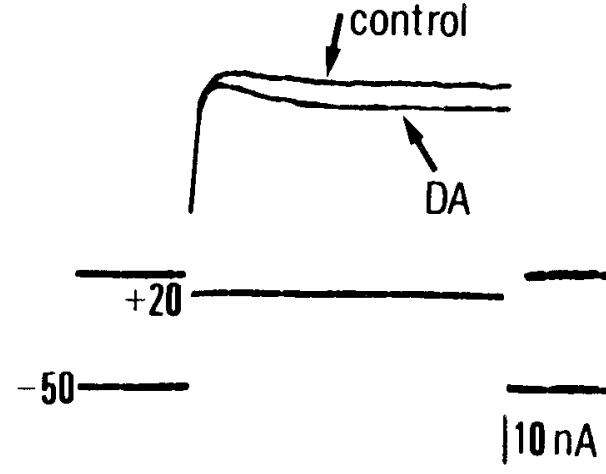

$20 \overline{\mathrm{ms}}$

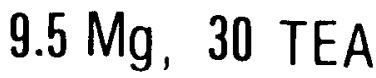

Figure 11. Composite effect of DA on the membrane currents of neuron F5. A, Bath application of $10 \mu \mathrm{M} D A$ decreases the plateau of the spike of cell F5 bathed in a saline containing $30 \mathrm{mM}$ TEA. B, Inward current of the same cell F5 recorded in a TEA-containing saline in which $\mathrm{Ca}^{2+}$ was replaced with $\mathrm{Ba}^{2+}$. Bath application of $10 \mu \mathrm{M}$ DA decreases the inward current. $\mathrm{C}$, The outward current of the same F5 neuron is recorded in a TEA-containing saline in which $\mathrm{Ca}^{2+}$ was replaced with $\mathrm{Mg}^{2+}$. The same application of DA also decreases the outward current.

decrease of the S-current and a decrease of the $\mathrm{Ca}^{2+}$ current, and that the latter had a predominant effect on the amplitude of the $\mathrm{Ca}^{2+}$ spike plateau.

Experiments were also performed to explore whether the DA ettects on the somatic spike of neuron F5 could be changed by modifying the amplitude of its $\mathrm{Ca}^{2+}$ plateau by altering the membrane potential and the frequency of stimulation. We then observed that DA decreased the duration of the $\mathrm{Ca}^{2+}$ spike of cell $\mathrm{F} 5$ regardless of the amplitude of its plateau phase.

\section{Discussion}

The present results indicate that DA, besides its previously described actions on molluscan neurons (Ascher, 1972; Berry and Cottrell, 1975; Swann and Carpenter, 1975; Gospe and Wilson, 1980; W. B. Adams et al., 1980; Akopyan et al., 1980; ChesnoyMarchais,1984), can also exert modulatory actions on the somatic spike by inducing either an increase or a decrease of its $\mathrm{Ca}^{2+}$. dependent plateau phase.

This paper also shows that in some identified snail neurons, each of these DA-induced modulatory actions on the somatic action potential is related to a decrease of a different specific conductance: the DA-induced increase of the $\mathrm{Ca}^{2+}$ spike plateau is associated with a cAMP-mediated decrease of a specific $\mathrm{K}^{+}$current, the $\mathrm{S}$ - current (Klein et al., 1982), whereas the DA-induced decrease of the spike platcau rcsults from a decrease in the $\mathrm{Ca}^{2+}$ conductance.

The DA-induced decrease in the CAMP-controlled S-current. The outward current decreased by DA is unaffected by the presence of both $30 \mathrm{~mm}$ TEA and $1 \mathrm{~mm}$ 4-AP in the extracellular medium, a drug combination which has been reported to block both $I_{D R}$ and $I_{A}$ in molluscan neurons. Moreover, the persistence of the effect of DA after the removal of $\mathrm{Ca}^{2+}$ from the extracellular medium indicates that the outward current component blocked by DA is neither $I_{C}$ nor other $\mathrm{Ca}^{2+}$-dependent outward current components (Byerly and Hagiwara, 1982). This conclusion is also supported by the results of previous experiments in steady-state voltage-clamp conditions (Deterre et al., 1982), showing that an intracellular injection of EGTA which blocked the $\mathrm{Ca}^{2+}$-dependent $\mathrm{K}^{+}$conductance had no effect on the DA-induced inward currents of cells E13 and F1.

Therefore, our experiments strongly suggest that the outward current suppressed by DA is similar to the S-current inactivated by 5-HT in Aplysia sensory neurons (Klein et al., 1982). Indeed, the same $\mathrm{K}^{+}$conductance decrease is produced by both DA and 5-HT in identified snail neurons (Deterre et al., 1982).

Another important similarity between the DA-sensitive outward current and the S-current is that they are both controlled by the intracellular CAMP concentration. The intracellular injection of CAMP 
mimicks both the depressing effect of DA on the outward currents of the $\mathrm{F} 1$ and $\mathrm{E} 13$ cells and the DA-induced inward current recorded from these neurons in steady state voltage-clamp conditions. Moreover, DA and CAMP were found to induce net currents which tit the same $I-V$ relation. The view that both DA and cAMP close the same population of channels is also supported by the inefficacity of cAMP when injected in the neuron in the presence of a maximal DA concentration, i.e., during a maximal closing of the ionic channels. Moreover, the same channel population could be maximally closed by either injecting CAMP or by increasing its intracellular concentration by applying either forskolin or IBMX and, in such cases, DA became in turn ineffective. In addition, the biochemical assay of the adenylate cyclase activity in single isolated $\mathrm{E} 13$ and $\mathrm{F} 1$ neurons confirmed that DA did stimulate the activity of the enzyme, thus increasing the intracellular CAMP concentration. Finally, on the basis of the results of experiments combining the application of DA and $5-\mathrm{HT}$, it is not difficult to accept that the $\mathrm{K}^{+}$channels closed by DA are the same as those inactivated by $5 \mathrm{HT}$ in the identified snail neurons and in the serisory neurons of Aplysia. The only differences are that, on the one hand, in the Aplysia sensory neurons, DA has no effect on the S-current and, on the other hand, $\mathrm{Ba}^{2+}$-containing media block the S-current in snail neurons but not in Aplysia neurons. Previous results had also shown that in snail neurons E13 and F1 the effects of 5-HT and DA on the cAMP-controlled $\mathrm{K}^{+}$conductance are mediated by different receptors (Deterre et al., 1982).

This mechanism of increase of the $\mathrm{Ca}^{2+}$ spike plateau in the identified molluscan neurons is different from that involved in the increase of the duration of the $\mathrm{Ca}^{2+}$ action potential evoked in frog and mammalian cardiac muscle fibers by the stimulation of the $\beta$ adrenergic receptors. CAMP is also involved in this effect, but the $\mathrm{Ca}^{2+}$ channels are the target of this transmitter modulation (see Reuter, 1983; Tsien, 1983).

The DA-induced decrease in $\mathrm{Ca}^{2+}$ conductance. The results of our experiments on the snail D2 ncuron are in favor of the view that the decrease in the $\mathrm{Ca}^{2+}$ plateau component of the somatic action potential is due to a decrease in $\mathrm{Ca}^{2+}$ conductance. The conditions in which the DA-induced decrease of the inward current was revealed, i.e., replacement of $\mathrm{Ca}^{2+}$ by $\mathrm{Ba}^{2+}$, presence of TEA in the extracellular medium in all experiments, presence of TTX and 4-AP in many of them, make it difficult to believe that DA could evoke an apparent decrease of the inward current by increasing a hidden outward current component. The experiment on the nystatin-treated, $\mathrm{Cs}^{+}$-loaded D2 cells also supports the idea that DA only affects the $\mathrm{Ca}^{2+}$ current even if, as recently described, outward currents carried mainly by $\mathrm{Cs}$ may be recorded in nystatin-treated, Cs-loaded molluscan neurons (Byerly and Hagiwara, 1982). In fact, if such currents were sometimes observed in some nystatin-treated snail neurons, we never observed them in the D2 neuron. Moreover, the I-V curves of Figure 6 confirm that the main effect of DA on neuron D2 is to decrease the $\mathrm{Ca}^{2+}$ conductance.

The maximal decrease of the $\mathrm{Ca}^{2+}$ current evoked by DA in the $\mathrm{D} 2$ cell and in other identified snail neurons was never larger than 30 to $40 \%$ of the control value. A similar reduction was observed by Dunlap and Fischbach (1980) in their study of the noradrenalineinduced decrease of $\mathrm{Ca}^{2+}$ conductance in chick embryo sensory neurons. In these neurons a similar decrease in $\mathrm{Ca}^{2+}$ conductance was also elicited by other transmitters such as GABA, 5-HT, enkephalin, and somatostatin. The molluscan peptide FMRF-amide can also evoke a decrease in $\mathrm{Ca}^{2+}$ conductance both in identified snail neurons in which DA evokes a $\mathrm{Ca}^{2+}$ conductance decrease and in other snail neurons in which DA had no effect on this conductance (see Colombaioni el al., 1985). The observations that $\mathrm{Ca}^{2+}$ conductance could be decreased by more than one transmitter and that DA could affect different ionic channels (Ascher, 1972; Berry and Cottrell, 1975; Swann and Carpenter, 1975; W. B. Adams et al., 1980; Akopyan et al. 1980; Gospe and Wilson, 1980; Chesnoy-Marchais, 1984) renders unlikely that the effect of DA is directly exerted on the $\mathrm{Ca}^{2+}$ channel. In this context, we have investigated whether an intracellular messenger was involved in the effect of DA on the $\mathrm{Ca}^{2+}$ conductance. Our experiments discard the intervention of an increase of the intracellular CAMP concentration in the mediation of the DA eftects, since DA did not stimulate the adenylate cyclase activity of the D2 cell and the intracellular injection of CAMP had no effect on the inward current recorded in this neuron. The possibility remains that DA may inhibit the activity of the adenylate cyclase. However, this was not observed in our single-cell enzyme assay experiments. A mechanism involving inhibition of the adenylate cyclase has been suggested for the $\mathrm{Ca}^{2+}$ conductance decrease evoked by $\alpha$-adrenergic stimulation of sympathetic ganglion neurons (Horn and McAfee, 1980; see McAfee et al., 1981), since $\alpha$-adrenergic stimulation has been reported to induce adenylate cyclase inhibition (Jakobs, 1979; Sabol and Nirembery, 1979). In anolher transmitter-induced $\mathrm{Ca}^{2+}$ current decrease, the one evoked by muscarinic agonists on the cardiac muscle fibers, an intervention of CGMP as second messenger has been postulated (Trautwein et al., 1982). cGMP had no effect on the $\mathrm{Ca}^{2+}$ current of the snail $\mathrm{D} 2$ cell. Intracellular $\mathrm{Ca}^{3+}$ was also a candidate for the role of second messenger mediating the effects of DA on the $\mathrm{Ca}^{2+}$ channels of the $\mathrm{D} 2$ neuron. There is good evidence that the intracellular $\mathrm{Ca}^{2+}$ plays a role in the mechanism of the $\mathrm{Ca}^{2+}$ current inactivation (see Chad et al., 1984). If DA was able to elicit a release of $\mathrm{Ca}^{2+}$ ions from an intracellular compartment, this could account for the decrease in $\mathrm{Ca}^{2+}$ conductance. The intracellular injections of EGTA in cell D2, even if they succeeded in causing an apparent removal of the inactivation, confirmed that intracellular $\mathrm{Ca}^{2+}$ does not intervene in the DA-induced decrease of $\mathrm{Ca}^{2+}$ current.

Duality of DA effects on single identificd snail nourons. The study of the effect of DA on the snail F1 and E13 neurons, on the one hand, and on the D2 neuron, on the other hand, shows that the effects of DA on the membrane conductance described above clearly involve two different mechanisms: one linked to the stimulation of adenylate cyclase and a different one affecting the $\mathrm{Ca}^{2+}$ current. The present study, however, has also shown that both DA effects may be observed in the same neuron. We do not yet know whether the two effects result from the activation of one or two different receptors. Neither do we know why the DA effect on the $\mathrm{Ca}^{2+}$ conductance predominates in the modulation of the cell body spike plateau, either from a particular receptor distribution or from a difference in the magnitude and/or the kinetics of the ionic currents.

Possible physiological signiticance of the DA-induced changes of the $\mathrm{Ca}^{2+}$ action potential. The modulation the $\mathrm{Ca}^{2+}$ channels at the synaptic endings may have great importance in the mechanism of transmitter release. The cell body of neurons carrying a $\mathrm{Ca}^{2+}$ spike and endowed with transmitter receptors has been a good model to analyze events which may produce a modulation of the transmitter release at the neuron endings. Thus, Klein and Kandel $(1978,1980)$ have shown that the 5-HT-induced increase of the soma action potential plateau of Aplysia sensory neurons could account for the mechanism of the presynaptic facilitation evoked by $5-\mathrm{HT}$ or the stimulation of some interneurons which underlies the "sensitization" of the gill withdrawal reflex. In contrast, Dunlap and Fischbach (1980) postulated that the GABA-induced decrease of $\mathrm{Ca}^{2+}$ conductance observed in chick embryo sensory ganglion neurons could account for the presynaptic inhibition at some of the dorsal root yaniglion cell endings in the spinal cord. A similar parallelism between decrease in the $\mathrm{Ca}^{2+}$ conductance of the soma membrane and presynaptic inhibition has been described in neuron L10 of Aplysia (Shapiro et al., 1980). The transmitter in this case has not yet been identified, but histamine was found to mimic its effects (Kretz et al., 1984).

In the context of such examples, it may be suggested that both actions of DA, on the S-current and on the $\mathrm{Ca}^{2+}$ current, could also participate in presynaptic mechanisms. If such were the case, a particular situation might exist in the endings of the neurons in which, as in neuron F5, DA might depress both the S-current and the $\mathrm{Ca}^{2+}$ current. In these neurons, the presynaptic DA effects could be 
unique, owing to the predominancc of the activation of a unique receptor, or dual, if DA activates two different kinds of receptors and if the receptors of each class are grouped together on separated membrane patches facing synaptic endings of different dopaminergic interneurons. Such a dual effect of synaptic transmitters has been a constant finding of those investigating the function of $\mathrm{mol}$ luscan synapses.

\section{References}

Adams, D. J., S. J. Smith, and S. H. Thompson (1980) lonic currents in molluscan neurones. Annu. Rev. Neurosci. 3: 141-167.

Adams, P. R. (1982) Voltage-dependent conductances of vertebrate neu rones. Trends Neurosci. 46: 116-119.

Adams, W. B., I. Parnas, and I. H. Levitan (1980) Mechanism of long-lasting synaptic inhibition in Aplysia neurone RIS. J. Neurophysiol. 44: 1148 1160 .

Akopyan, A. R., L. S. Bocharova, and N. K. Chemeris (1980) Cyclic AMP dependent dopamine responses in snail neurone. Comp. Biochem. Phys iol. $6 / C \cdot 211-214$

Akopyan, A. R., V. Iljin, and N. K. Chemeris (1984) Dopamine-induced modulation of Ca-component of action potential in neuronal soma of $\mathrm{L}$. Stagnalis mollusc. Biofizika 29: 284-288 (in Russian).

Ascher, P. (1972) Inhibitory and excitatory effects of dopamine on Aplysia neurones. I. Physiol. (Lond.) 315: 531-548.

Bean, B. P., M. C. Nowycky, and R. W. Tsien (1984) $\beta$-Adrenergic modulation of calcium channels in frog ventricular heart cells. Nature 307: 371-375.

Berry, M. S., and G. A. Cottrell (1975) Excitatory, inhibitory and biphasic synaptic potentials mediated by an identified dopamine-containing neu rone. J. Physiol. (Lond.) 244: 589-612

Bockaert, J., M. Hunzicker-Dunn, and L. Birnbaumer (1976) Hormone-stimulated desensitization of hormone-dependent adenylate cyclase. J. Biol Chem. 251: 2653-2663

Boyle, M. B., M. Klein, S. J. Smith, and E. R. Kandel (1984) Serotonin increases intracellular $\mathrm{Ca}^{2+}$ transients in voltage clamped sensory neurons of Aplysia californica. Proc. Natl. Acad. Sci. U. S. A. 81: 7642-7646.

Brum, G., V. Flockerzi, F. Hofman, W. Osterrieder, and W. Trautwein (1983) Injection of catalytic subunit of CAMP-dependent protein kinase into iso lated myocytes. Pflügers Arch. 398: 146-154.

Brum, G., W. Osterrieder, and W. Trautwein (1984) B-Adrenergic increase in the calcium conductance of cardiac myocytes studied with the patch clamp. Pflügers Arch. 401: 111-118.

Byerly, L., and S. Hagiwara (1982) Calcium currents in internally perfused nerve cell bodies of Lymnaea stagnalis. J. Physiol. (Lond.) 322: 503-528.

Canfield, D. R., and K. Dunlap (1984) Pharmacological characterization of amine receptors on embryonic chick sensory neurones. Br. J. Pharmacol. 82: $557-561$

Castelluci, V. F., E. R. Kandel, J. H. Schwartz, F. D. Wilson, A. C. Nairn, and $P$. Greengard (1982) Intracellular injection of the catalytic unit of cyclic AMP-dependent protein kinase stimulates facilitation of transmitter release underlying behavioral sensitization. Proc. Natl. Acad. Sci. U. S. A. 77 : 7492-7496.

Chad, J., R. Eckert, and D. Ewald (1984) Kinetics of calcium-dependent inactivation of calcium current in voltage-clamped neurones of Aplysia californica. J. Physiol. (Lond.) 347: 279-300.

Chesnoy-Marchais, D. (1984) Effecls of dopannirie on the Aplysia burster R15. Brain Res. 304: 83-91

Colombaioni, L., D. Paupardin-Tritsch, P. P. Vidal, and H. M. Gerschenfeld (1985) The neuropeptide FMRF-amide decreases both the $\mathrm{Ca}^{2+}$ conduct ance and a cyclic $3^{\prime}, 5^{\prime}$-adenosine monophosphate-dependent $\mathrm{K}^{+}$conductance in identified molluscan neurons. J. Neurosci. 5: 2533-2538.

Deterre, P., D. Paupardin-Trisch, J. Bockaert, and H. M. Gerschenfeld (1981) Role of cyclic AMP in a serotonin-evoked slow inward current in snail neurones. Nature 290: 783-785.

Deterre, P., D. Paupardin-Trisch, J. Bockaert, and H. M. Gerschenfeld (1982) cAMP-mediated decrease in $\mathrm{K}^{+}$conductance evoked by serotonin and dopamine in the same neuron: A biochemical and physiological single-cell study. Proc. Natl. Acad. Sci. U. S. A. 79: 7934-7938.

Dunlap, K., and G. D. Fischbach (1980) Neurotransmitters decrease the calcium conductance activated by depolarization of embryonic chick sensory neurones. J. Physiol. (Lond.) 317: 519-535.

Eckert, R., and D. Tillotson (1981) Calcium.mediated inactivation of the calcium conductance in cesium-loaded giant neurones of Aplysia californica. J. Physiol. (Lond.) 314: 265-280.
Galvan, M., and P. R. Adams (1982) Control of calcium current in rat sympathetic neurons by norepinephrine. Brain Res. 244: 135-144.

Gerschenfeld, H. M., D. Paupardin-Tritsch, L. Colombaioni, P. Deterre, and P. P. Vidal (1984) Dual mechanism of modulation of calcium spike duration by dopamine, serotonin and the peptide FMRF amide. In Abstracts of the 1984 Regional Meeting of the IUPS, Jerusalem, p. 211, Jerusalem.

Giles, W., and S. J. Noble (1980) Changes in membrane current in bullfrog atrium produced by acetylcholine. J. Physiol. (Lond.) 261: 103-123.

Gospe, S. M., and W. A. Wilson (1980) Dopamine inhibits burst firing of neurosecretory cell R15 in Aplysia californica: Establishment of a doseresponse relationship. J. Pharmacol. Exp. Ther. 214: 112-118.

Hagiwara, S., and L. Byerly (1981) Calcium channel. Annu. Rev. Neurosci. 4: $69-125$.

Hino, N., and R. Ochi (1980) Effect of acetylcholine on membrane currents in guinea-pig papillary muscle. J. Physiol. (Lond.) 307: 183-197.

Hockberger, P. E., and J. E. Connor (1983) Cyclic AMP injections into Aplysia and Archidoris neurons induce sodium currents with unique electrical and pharmacological propertıes. Soc. Neurosci. Abstr. 9: 1190.

Horn, J. P., and D. A. McAffee (1980) Alpha adrenergic inhibition of calciumdependent potentials in rat sympathetic neurones. J. Physiol. (Lond.) 301 : 109-204.

imbert, M., D. Chabardès, M. Montegut, A. Clique, and F. Morel (1975) Adenylate cyclase activity along the rabbit nephron as measured in single isolated segments. Pflügers Arch. 354: 213-228.

Jakobs, K. H. (1979) Inhibition of adenylate cyclase by hormones and neurotransmitters. J. Coll Mol. Endocrinol. 16: 147-150.

Kaczmarek, I. K., K. R. Jennings, F. Strumwasser, A. C. Nairn, A. C. Walter, and P. Greengard (1980) Microinjection of catalytic subunit of CAMP. deperıdent protein kinase enhances calcium action potentials of bag cell neurons in cell culture. Proc. Natl. Acad. Sci. U. S. A. 77: 7487-7491.

Kerkut, G. A., J. D. C. Lambert, R. J. Gayton, J. E. Loker, and R. J. Walker (1975) Mapping of nerve cells in the suboesophageal ganglia of Helix aspersa. Comp. Biochem. Physiol. 50A: 1-25.

Klein, M., and E. R. Kandel (1978) Presynaptic modulation of voltage dependent $\mathrm{Ca}^{2+}$ current: Mechanism for behavioral sensitization in Aplysia californica. Proc. Natl. Acad. Sci. U. S. A. 75: 3512-3516.

Klein, M., and E. R. Kandel (1980) Mechanism of calcium current modulation underlying presynaptic facilitation and behavioral sensitization in Aplysia. Proc. Natl. Acad. Sci. U. S. A. 77: 6912-6916.

Klein, M., J. S. Camardo, and E. R. Kandel (1982) Serotonin modulates a new potassium current in the sensory neurons that show presynaptic facilitation in Aplysia. Proc. Natl. Acad. Sci. U. S. A. 79: 5713-5717.

Kostyuk, P. G. (1980) Calcium ionic channels in electrically excitable membrane. Neuroscience 5: 945-959.

Kretz, R., E. Shapiro, C. H. Bailey, and E. R. Kandel (1984) Histamine as a putative transmitter of presynaptic inhibition: Effect onto the $\mathrm{Ca}^{++}$channel in Aplysia neurons. In Abstracts of the 1984 Regional Meeting of the IUPS, Jerusalem, p. 126, Jerusalem.

McAfee, D. A., B. K. Henon, J. P. Horn, and P. Yarowsky (1982) Calcium currents modulated by adrenergic receptors in sympathetic neurons. Fed. Proc. 40: 2246-2249.

Osterrieder, W., G. Brum, J. Hescheler, W. Trautwein, V. Flockerzi, and F Hofmann (1982) Injection of subunits of cyclic AMP-dependent protein kinase into cardiac myocytes modulates $\mathrm{Ca}^{2+}$ current. Nature 298: 576578.

Paupardin-Tritsch, D., P. Deterre, and H. M. Gerschenfeld (1981) Relationship between two voltage-dependent serotonin responses of molluscan neurones. Brain Res. 217: 201-206.

Reuter, H. (1983) Calcium channel modulation by neurotransmitters, enzymes and drugs. Nature 301: 569-574.

Reuter, $H_{\text {., }}$ and $H$. Scholz (1977) The regulation of the calcium conductance of cardiac muscle by adrenaline. J. Physiol. (Lond.) 264: 49-62.

Reuter, H., A. B. Cachelin, J. E. De Peyer, and S. Kobuku (1983) Modulation of calcium channels in cultured cardiac cells by isoproterenol and 8-bromocAMP. Cold Spring Harbor Symp. Quant. Biol. 48: 193-200.

Sabol, S. L., and M. Niremberg (1979) Regulation of adenylate cyclase of neu uroblastoma $\times$ glioma hybrid cells by adrenergic receptors. I. Inhibition of adenylate cyclase mediated by $\alpha$-receptors. Proc. Natl. Acad. Sci. U. S. A. 254: 1913-1920.

Seamon, K. B., and J. W. Daly (1982) Forskolin: Unique diterpene activator of cyclic AMP generating system. J. Cyclic Nucleotide Res. 7: 201-224.

Shapiro, E., V. F. Castellucci, and E. R. Kandel (1980) Presynaptic inhibition in Aplysia involves a decrease in the $\mathrm{Ca}^{2+}$ current of the presynaptic neuron. Proc. Natl. Acad. Sci. U. S. A. 77: 1185-1189. 
Shuster, M. J., J. S. Camardo, S. A. Siegelbaum, and E. R. Kandel (1985) Cyclic AMP-dependent protein kinase closes the serotonin-sensitive $\mathrm{K}^{+}$ channels of Aplysia sensory neurones in cell-free membrane patches. Nature 313: 392-395

Siegelbaum, S., J. S. Camardo, and E. R. Kandel (1982) Serotonin and cyclic AMP close single $\mathrm{K}^{+}$channels in Aplysia sensory neurones. Nature 299. 413417.

Swandulla, D., and H. D. Lux (1984) Changes in ionic conductances induced by cAMP in Helix neurons. Brain Res. 305: 115-122

Swann, J. W., and D. O. Carpenter (1975) Organisalion of receptors for neurotransmitters on Aplysia neurones. Nature 258: 751-754.

Tillotson, D. (1979) Inactivation of $\mathrm{Ca}^{2+}$-conductance dependent on entry of
$\mathrm{Ca}^{2+}$-ions in molluscan neurones. Proc. Natl. Acad. Sci. U. S. A. 76: $1497-$ 1500 .

Trautwein, W., J. Taniguchi, and A. Noma (1982) The effects of intracellular cyclic nucleotide and calcium on the action potential and acetylcholine response of isolated cardiac cells. Pflügers Arch. 392: 307-314.

Tsien, R. W. (1977) Cyclic AMP and contractile activity in the heart. Adv. Cyclic Nuclcotide Res. 8: 363420

Tsien, R. W. (1983) Calcium channels in excitable cell membranes. Annu. Rev. Physiol. 45: 381-358.

Tsier, R. W., and S. Siegeltuaun (1980) Excitable lissues: The heart. In Physiology of Membrane Disorders, T. E. Andreoli and J. F. Hoffman, eds., pp. 517-538, Plenum Press, New York. 